\title{
MAKING WHIPPED CREAM OR GETTING HIGH: PRODUCT MISUSE OR A FAILURE TO WARN?
}

\author{
Richard J. Hunter, Jr. \\ Professor of Legal Studies, Seton Hall University \\ hunterri@shu.edu \\ Sandra Solano \\ Controller, Leland Gas Technologies \\ sandysolano212@yahoo.com
}

\begin{abstract}
This paper will consider several legal issues presented by this scenario: is the Whip-it! a defective product? is the manufacturer or the seller of the Whip-it! liable for not properly warning a prospective plaintiff about the dangers inherent in the use of the product? Is Walter a "foreseeable" user of the product? Has the plaintiff misused the product to such an extent that he or she would be unable to recover for any injuries? Would any other defenses be potentially available to the defendant? These questions will be analyzed in the context of Starn v. Smoke Island and Jenkins v. W.L. Roberts, Inc.
\end{abstract}

KEY WORDS: Products Liability; Defective Products; Failure to Warn; Whip-it!; Misuse; Assumption of Risk

\section{Council for Innovative Research}

Peer Review Research Publishing System

Journal: Journal of Social Sciences Research

Vol. 8, No. 3

jssreditor.cir@gmail.com

www.jssronline.com 


\section{AN INTRODUCTION AND OVERVIEW}

Consider this scenario: Walter Ryker is a thirty-two year old advertising account executive. In all respects, he is a "nomal, regular guy"... except that he has one "secret"... He frequently inhales "whip -its." Walter is seriously injured when he decides to inhale the Whip-it! (brand name) provided by one of his friends. The whip-it had been purchas ed by Walter's cousin, Raymond, from the "Three Leaf Smoke Shop," located in Chelsea, New York. The product contains a set of instructions indicating its use in a restaurant or food service preparation environment. In addition, there is a warning on the individual canister that states: "Dangerous: Not for inhalation."

The area of law termed products liability is a mixture of both contract law (involving either express or implied promises, found in the law of warranties) and tort law (based upon specific conduct, oftentimes reflected in a negligence standard, or actions based on fraud or misrepresentation). (Adapted from Hunter, Amoroso \& Shannon, 2012a). In general terms, products liability refers to the obligations or duties of manufacturers, wholesalers or other middlemen, retailers/sellers, as well as other parties involved in the vertical marketing chain (Restatement (Second) of Torts, Section 402A, comment $f$, 1965), to consumers, buyers, purchasers, users, and potentially even "bystanders" when a product is found to be defective. No matter what the theory of liability might be, the predicate of a suit in products liability is a defective product. A defect can arise from three common sources:

- A manufacturing or production defect-that occurs from a random and a-typical breakdown in the manufacturing process;

- A design defect-that is characteristic of a whole product line (such as the infamous Ford Pinto automobile; or more recently, General Motors problems with faulty ignition switches); or

- A marketing defect-involving inadequate warnings concerning risks or dangers, or inadequate instructions relating to how to properly (or safely) use a product (many cases in the are a of a marketing defect involve food, drugs, or more recently, children's toys or car seats). (Hunter \& Montuori, 2013).

Under the common law, there were three theories under which a plaintiff could bring a suit for personal injury or property damage allegedly caused by a defective product. (Hunter, Amoroso \& Shannon, 2012b). Later, a fourth theory, strict liability in tort, was developed as a specific cause of action in products cases. These theories may be summarized as follows:

\subsection{Theories Under Which Plaintiffs Might Proceed: Negligence, Fraud, Warranty- Leading to the Adoption of Strict Liability in Tort}

In a suit based in products liability, the plaintiff will typically plead or allege a number of alternative theories of liability. As such, a "products liability action" may be:

"Any action against a manufacturer or seller for recovery of damages arising out of personal injury, death, or property damage allegedly caused by a defective product whether the action is based in strict tort liability, $s$ trict product liability, negligence, misrepresentation, breach of express or implied warranty, or any other theory or combination of theories." (Texas Civil Practice and Remedies Code, as amended, 1987).

Negligence requires proof that a product was designed or manufactured in an "unreasonable manner," or that the warnings or directions were inadequate under the circumstances. (E.g., Garnes v. Gulf \& Western Mfg. Co., 1986). An action based on the theory of misrepresentation or fraud focuses on proof of a false representation of a material fact (found in words, actions, concealment, or in some cases even silence, where the common law found a positive "duty to speak"), upon which a plaintiff reasonably relied in entering into a contract or agreement. At common law, proof of falsehood was required in order to prove a misrepresentation, and proof of scienter ("the intent to deceive"), arising from either "knowledge of falsity or "reckless dis regard of the truth," was a part of the "prima facie" proof required in cases of fraud. (Generally, Fischer \& Powers, p. 313, 1988). Often times, an assertion of "safety" or of a "safe product" would form the basis of an allegation of fraud-especially in cases of products intended for use by children. As Browne and Biksacky (p. 221, 2013) noted: "Consumers must trust that companies are producing safe products, but this trust is often in jeopardy because consumers realize businesses do not always provide all the required product information."

Warranty actions are essentially based on contract promises, either express or implied. Because warranties arose out of the law of contracts, warranties are subject to disclaimers on the part of a seller and could be severely limited in their scope. Warranty actions are also subject to notice requirements (that is, the injured party had to give the party causing the injury a notice that damage/injury had occurred within a rather limited period of time-in most cases, no more than three months), and the plaintiff was required to prove reliance on specific words or promises made by a seller.

Warranties under the Uniform Commercial Code (UCC) (1952/1999) were only applicable in cases involving the sale of goods, and not in the myriad of other types of transactions that resulted in goods or property reaching the hands of a consumer-most notably leases or bailments. Under the common law, privity of contract between a manufacturer and the consumer/buyer (temed vertical privity) was likewise problematic, although the requirement of vertical privity was later severely limited in MacPherson v. Buick Motors (1916) which overturned the privity doctrine established in Winterbottom v. Wright (1842). In MacPherson, Justice Cardozo reasoned:

"If the nature of a thing is such that it is reasonably certain to place life and limb in peril when negligently made, it is then a thing of danger. Its nature gives warning of the consequences to be expected. If to the element of 
danger there is added knowledge that the thing will be used by persons other than the purchaser, and used without new tests, then, irrespective of contract, the manufacturer of this thing of danger is under a duty to make it carefully." (MacPherson v. Buick Motors, p. 1053, 1916).

Under the common law, there was also a rule that limited a manufacturer's liability to the actual purchaser of a product and not to any other parties. This aspect of privity was greatly modified with the decision in Henningsen v. Bloomfield Motors (1960), which saw the expansion of liability (horizontal privity) under the warranty of merchantability to pers ons other than the consumer/buyer. This expansion may be seen in UCC Section 2-318, which significantly expanded the range of potential plaintiffs in a warranty action.

\subsection{Strict Liability in Tort}

Drawbacks and limitations inherent in the three common law forms of action led to the development of the modem and now preferred theory in products liability cases - the creation of strict (or absolute) liability in tort. (See Greenman v. Yuba Power Products, Inc., 1963).

"To establish the manufacturer's liability it was sufficient that plaintiff proved that he was injured while using the Shopsmith in a way it was intended to be used as a result of a defect in design and manufacturing of which plaintiff was not aware that made the Shopsmith unsafe for its intended use..." (Greenman v. Yuba Power Products, Inc., p. 901,1963).

The theory of strict liability, later embodied in Section 402A of the Restatement (Second) of Torts (1965), focuses exclusively on the existence of a product defect and not on the conduct of the defendant (negligence), or on specific words or promises (warranty/ misrepresentation/fraud). At its essence, "the emphasis of the strict liability doctrine is upon the safety of the product, rather than the reasonableness of the manufacturer's conduct." (Feldman v. Lederle Laboratories, 1984). Strict liability permits an injured party, broadly defined, to sue a manufacturer directly, even in the absence of privity; will permit no disclaimers of the manufacturer's duty; and has obviated the strict requirements of notice under warranty actions (often as short as three months), preferring instead to abide by more generous statute of limitation provisions. Under the UCC, the Statute of Limitations can never be less than 1 year and no more than 4 years.

\section{TYPES OF PRODUCT DEFECTS}

As noted, there are three general sources of a product defect: a manufacturing or production defect; a design defect; and a marketing defect, reflected in issues relating to warnings and labels. Section two discusses the types of defects in detail.

\subsection{Production or Manufacturing Defects}

A production or manufacturing defect exists "if the product differs from a manufacturer's intended result or if the product differs from apparently identical products from the same manufacturer." (Committee on Standard Jury Instructions, 1986). There are various formulations concerning the existence of a production or manufacturing defect:

- A product which comes off the assembly line in a substandard condition in comparison with other identical units, called "the deviation from the norm" test-sometimes termed as the Lee Test found in Lee v. Volkswagen of America, Inc. (1984).

- Manufacturing defects are imperfections that occur in a typically small percentage of products of a given design as a result of the fallibility of the manufacturing process. [If there are a large number of individual defects, this will probably be seen as a design defect, and not an isolated manufacturing or production defect.]

- Products that do not conform to their intended design. (Restatement (Third) of Torts: Products Liability, Section 2, 1997).

- Products that do not conform to the great majority of manufactured products within the design.

- $\quad$ Products that are misconstructed. (Rix v. General Motors Corp., 1986).

- Defects which result from a mishap in the manufacturing process or from improper workmanship, or because defective materials were used. This iteration has been applied to component parts, assembled by the primary manufacturer. (See, e.g., Braucher, p. 1417, n.57, 1985).

- Products which do not conform to the manufacturers own specifications. (Escola v. Coca-Cola Bottling Co., 1944).

In a large majority of manufacturing defect cases, courts use a simple test to detemine if a product is defective: the "reasonable expectations of the buyer or consumer." (Gray v. Manitowoc Co., Inc., 1985; Tincher v. Omega Flex, Inc., 2013).

\subsection{Design Defects}

Design defects occur where the design of the product makes the product unreasonably dangerous for its intended purpose. Courts will use industry standards, trade customs or "trade usage," or applicable manufacturing codes in order 
to determine the existence of a design defect. Design defect cases require expert proof, which must be authenticated; and the expert who offers such testimony must be qualified to give objective testimony or render a professional opinion. (Ford Motor Co. v. Bland, 1974).

The requirement of expert proof implicates what is called the Daubert Rule and may entail a judge acting as a "judicial gate keeper" in order to assure that any alleged expert testimony meets a basic threshold based on real and not "junk" science. (Daubert v. Merrell Dow Phamaceuticals, 1995; Hunter \& Montuori, p. 240, n.42, 2013). The Court noted: "Unlike an ordinary witness, an expert is permitted wide latitude to offer opinions, including those that are not based on firsthand knowledge or observation. Presumably, this relaxation of the usual requirement of firs thand knowledge--a rule which represents a most pervasive manifestation of the common law insistence upon the most reliable sources of information--is premised on an assumption that the expert's opinion will have a reliable basis in the knowledge and experience of his discipline." (Daubert v. Merrell Dow Pharmaceuticals, p. 589, 1995, cited in Kinser v. Gehl Company, 1999).

In general, a product will be judged as to the existence of a design defect when it is manufactured, distributed, or sold. (Mickle v. Blackmon, 1969/1970; Boatland of Houston, Inc. v. Bailey, 1980). So-called "state of the art" testimony will be utilized to detemine the technology available at this point. (Ausness, 2012). Galligan, et al. (p. 579, 2007) note that when a manufacturer argues "state of the art," he may be seeking to introduce evidence "(1) of scientific unknowability of the risks posed by the product, (2) that other manufacturers used similar designs, or (3) that there was no available technology to make the product safer."

Even though still essentially voluntary (Bernstein, 2013), in recent years, many courts have also imposed a duty on the part of a manufacturer to at least issue a warning concerning dangers or even to recall products which were not necessarily defective when designed or manufactured, but which may have become defective at a later date, perhaps through obsolescence, a change in technology, or the passing of time-especially if there is a substantial risk of ham to a large number of persons, and if the change required to make the product safer or substantially more safe would be a minimal one. (E.g., Cover v. Cohen, 1984).

Design defect cases recognize the fact that there is a risk involved in the production of many products and then the question is asked: Did the manufacturer take reasonable steps to correct or at least minimize the risk?

In determining the existence of a design defect, courts must necessarily balance the economic interests of the manufacturer and the usefulness of a product against the safety interests of the consumer. In fact, it must also be recognized that "[m]any products can not be made safe at all . . . such products may be useful and desirable." (Center Chemical Co. v. Parzini, pp. 582-83, 1975). Some courts apply what is termed a "risk-utility" analysis. (Wade, 1973). Under an interpretation found in Welch v. Outboard Marine Comp., 1973), the proper standard to be applied in this balancing process is as follows:

"A product is defective because of its design and unreasonably dangerous if the reasonable seller, having been made aware of the danger involved, would not sell the product." (Owen, 2008, citing Welch v. Outboard Marine Corp., pp. 337, 1973).

In many cases, an inquiry will relate to the cost of any change. Courts will frequently inquire whether or not the hazard, danger, or risk could have been obviated at a slight cost. (For example, selling or manufacturing a lawnmower without a dead man's switch which could have been added or supplied for less than $\$ 5.00$, as seen in Burch v. Sears Roebuck (1983)).

The state of New Jersey provides a statement of the majority view conceming the obligation of the parties in proving a design defect. New Jersey courts require that the plaintiff must prove there is a "practical and technically feasible" alternative design that will not impair the core function of the product or unreasonably increase its cost. (Montal, 1989 citing N.J. Stat. Ann. § 2 A:58C-3.a(1)).

\subsection{Product Warnings}

The third source of a product defect, sometimes temed a "marketing defect," lies in the area of warnings and labels attached to products. In general, in order for a warning to be adequate, it must make the product safe for both its intended and foreseeable uses (including any potential foreseeable misuse).

There are three criteria that are used by the courts to detemine the adequacy of a warning:

- "A warning must be displayed in such a way as to reasonably "catch the attention" of the person expected to use the product. (This element deals with such factual questions as size, position, and even the color of the warnings.)

- A warning must fairly apprise a reasonable user of the nature and extent of the danger and not minimize any danger.

- A warning must instruct the user as to how to use the product in such a way as to avoid the dangeressentially, how to safely use the product." (Hunter, Shannon \& Amoroso, p. 19, 2012).

These three elements are the heart of the complaint relating to the nature of the injury from the use of the Whip-it! 
Courts emphasize that manufacturers must anticipate reasonable risks and wam of these risks. However, "a warning need only be one that is reasonable under the circumstance." (Levin v. Walter Kidde \& Co., 1968). Manufacturers must also appreciate the "environment of use" of a product—as was determined in Spruill v. Boyle-Midway, Inc. (1962).

There may be a close relationship between a defect arising as a result of a failure to warn and a defect arising as a result of a defect in the design of a product. In some jurisdictions, the failure to warn may be seen as evidence of a design defect in the product itself because proper instructions and wamings are seen as an integral part of the design of a product itself! (Fischer \& Powers, 1988).

The Spruill case was decided within the context of "inherently dangerous products," the issue discussed in Thomas $v$. Winchester (1852), where the "danger of injury stems from the product its elf, and not from any defect in it" and or not resulting from negligence in the course of manufacture. Spruill establishes that the basic test in a product waming case should be "reasonable foreseeability" and that a manufacturer must anticipate the environment which is nomal for the use of its product.

The requirement of Spruill that the product must be "inherently dangerous" in order for there to be a duty to warn is no longer the law. A warning is now required for any product, which may be considered dangerous if used in its intended fashion as a result of a defect in its design-today encompassing a wide variety of consumer products, food products, and pham aceuticals.

By focusing on the warnings, the jury may be persuaded that a manufacturer should have changed or modified its warnings rather than change its design. But in either case, the product is defective and liability would follow!

Some important points have been made by courts in discussing issues relating to product warnings, which may be helpful in the consideration of Starn v. Smoke Island-especially those relating to knowledge on the part of a plaintiff of a risk from misusing an otherwise non-defective or safe product.

A warning is not adequate if it minimizes the danger associated with a product, especially if there is a known and documented problem. An example may be seen in the following warning: "Inhalation of asbestos in excessive quantities over long periods of time may be hamful." The Fifth Circuit Court of Appeals held in Borel v. Fireboard Paper Products Corp. (1973), that this was not adequate to inform insulation workers of the substantial risk of contracting asbestosis and cancer because of the presence of the word "may" in the warning.

However, a majority of American courts have ruled that there is no duty to warn about an obvious or ge nerally known danger or where it can be shown that a plaintiff has actual knowledge about the danger associated with the use of a product. This is substantially an "assumption of risk" defense that may be relevant in determining ultimate responsibility for an injury-and may be a factor in determining the outcome in Starn.

Restatement (Second) of Torts, Section 402A, Comment j (1965) tracks this point and states: "A seller is not required to warn with regard to products, or ingredients in them, when the danger or potentiality of danger, is generally known and recognized."

In such a case, it is argued that the warning would serve no practical or useful purpose since it would tell the user nothing that he does not already know. Some states, for example, New Jersey, have in the past required that wamings must still be provided (and posted conspicuously) —even relating to obvious dangers - because of overriding public policy considerations which require that the maximum amount of information be given to consumers in all cases. Would this same consideration hold in the case of the intentional misuse of a product or in a state that does not strictly require a warning under these circumstances?

\subsection{To Whom Must Warnings Be Given?}

Unless required by an administrative agency or under some statutory authority, warnings must be given to the user or consumer, but not to the general public, because it might be difficult or impossible to effect or monitor such warnings. Where products are sold to "sophisticated industrial users" for their use in the manufacturing process, the manufacturer or supplier is not required to warn the purchaser's employees. (E.g., Martinez v. Dixie Carriers, 1976; Fischer \& Powers, p. 267, 1988). The supplier can escape liability by adequately warning and training the industrial purchaser. (See Natural Gas Odorizing v. Downs, 1997). This rule would only apply to producergoods, as opposed to consumer goods, which are defined as goods purchased for "personal, family or household use." (Uniform Commercial Code, Section 2 201(11), 1952/1999).

Conceming warnings relating to prescription drugs, a manufacturer's duty to warn is limited to an obligation to advise the prescribing physician of any potential dangers that may result from the drug's use. This is called the "learned intermediary" exception, found in Reyes $v$. Wyeth Laboratories (1974). Thus, manufacturers have no duty to warn the patient directly. In such cases, the manufacturer will be insulated from liability and any "patient redress" will be limited to an action for negligent prescribing or for failing to disclose the risks associated with the drug against the prescribing physician-and not the manufacturer. (Galligan et al., p. 594, 2007, citing Toole v. Baxter Healthcare Corp., 2000). As to nonprescription (over-the-counter) drugs, the manufacturer must warn consumers directly by and through adequate labels, warnings, and directions.

The "learned intermediary" exception has been held not to apply where a prescription drug such as a vaccine is distributed in a mass immunization program in which the drug manufacturer participated, or where a drug is distributed 
through public health clinics. (Davis v. Wyeth Laboratories, Inc., 1968). An exception may also apply in the case of birth control pills or antibiotics. (Lukaszewicz v. Ortho Phamaceutical Comp., 1981). In such cases, the role of the physician is minimal or perhaps practically nonexistent. A direct consumer warning may also be required when a manufacturer advertises a prescription drug to the general public.

As noted earlier, there may be a requirement to wam after the purchase of a product. A manufacturer may incur statutory liability for failing to warn relating to dangers in the use of a product which come to its attention after manufacture or sale which occur as a result of advancements in the "state of the art," or where the manufacturer has been made aware of dangers in the use of the product.

Whether such a waming must be given may depend on:

- The degree of danger involved;

- The number of instances reported; and

- The cost of any change to the product that might be required in relation to the danger perceived.

The basic elements of proof, theories of liability, and the nature of required warnings in products liability provides the backdrop for a discussion of an unusual case involving a product called a Whip-it!

\section{JASON STARN AND THE WHIP-IT!}

In recent years, manufacturers, distributors, and retailers of whip cream nitrous oxide chargers have been the target of an increasing number of lawsuits filed by plaintiffs claiming injury from the use of the canisters based upon a theory of negligence. The canisters, manufactured by Whip-it! (there are perhaps no more than three international manufacturers of the product), are known to be used as a recreational drug. Plaintiffs allege that they have suffered a variety of injuries, including spinal cord injuries directly related to prolonged recreational inhalation of the canisters. Whip-it!s are readily available from a wide array of retailers, including most major drug stores, kitchen supply shops, and supermarkets - and interestingly from smoke shops or "head shops." The complaints uniformly allege that the sellers have a duty to warn the public of the dangers of inhaling the canisters on its packaging. One such case was filed by Jason Starn in the state of Califomia. (Adapted from Furillo, 2013).

From a medical point of view, it is well documented that prolonged use of nitrous oxide is known to cause B-12 depletion in the body. The depletion of B-12 is known to increase the risk of spinal cord injury. [See Appendix I for a summary of the documented physical effects of inhaling nitrous oxide.] Manufacturers will generally print "Do Not Inhale" on the packaging in which the canisters are sold, but not on the individual canisters. In addition, the Whip-it! brand website includes the following disclaimer relating to product misuse:

"Whip-it! cream chargers must only be used for the purpose of food preparation."

The Whip-it! website (2015) also includes the following description relating to the purpose of the product: "Food grade $\mathrm{N} 2 \mathrm{O}$ is used as a propellant for whipping cream, which dissolves in the liquid cream. As the cream is released from the whipper, the gas expands and in doing so whips the cream into foam." [See Appendix II for a statement of the manufacturer regarding the product.]

The inhalation of the Whip-it! has been reported by law enforcement to be the cause of numerous deaths, fatal car accidents, and even rape. (Furillo, 2013). Recent figures show that Whip-It's have become the recreational "drug of choice" among many young adults. Experts believe they have gained in popularity because they can be used with regularity withoutshowing up on a drug test. According to a report by the Substance Abuse and Mental Health Services Administration (SAMHSA), over 12 million users in the United States have tried inhaling nitrous oxide at least once. (SAMHSA, 2008, 2013). Inhalation of the nitrous oxide gas produces a relatively brief but potent high to users. Although the possession of nitrous oxide itself is not per se illegal under either federal or state law, many individual states have passed laws outlawing the illegal use of nitrous oxide. At the time of the filing of the lawsuit by Jason Starn, there was no law on the books in California prohibiting the possession or use of nitrous oxide canisters.

Experts maintain that the unlawful use of Whip-it! canisters has been widely ignored by authorities and has largely remained unregulated. There is a stark anomaly: While it might be illegal to inhale nitrous oxide in order to get high, there is no existing law making it a crime to sell nitrous oxide to those who might plan to inhale it. Similar to products such as adhesives and solvents, which are also commonly misused, it may be impossible to determine whether the canisters are being sold for the purposes of inhalation or for the legitimate use for which they were intended. There may, however, be one clue: If the canisters are being sold in places such as tobacco stores or head shops, it would seem obvious that they are being sold to customers who likely intend to inhale it. Likewise, if the product is being sold from a store which specializes in sales of traditional kitchen supplies such as a Bed, Bath \& Beyond or a restaurant supply house, it might be fair to assume the product was being purchased for its intended use. However, in either case, it would be highly unlikely that any retailer would directly ask a customer why they were buying or how they were using a product.

However, the argument that the general public is not aware of the dangers of inhaling nitrous oxide would be very difficult, if not impossible, to maintain as well. Perhaps the most highly publicized example of the dangers of using a Whip-it! was the 2012 hospitalization of actress Demi Moore. According to an ABC News report, Moore had a seizure 
and was semi-conscious after inhaling the product. (Allen, 2015). The reports were widely circulated in all types of the media.

In addition, during the last decade outside of the state of Califomia, several high profile cas es involving the use of nitrous oxide have been fought in the courts. A well publicized incident involved the case of Richard A. Guy, Jr., a student at MIT, who died in 1999 as a result of asphyxiation after inhaling nitrous oxide canisters taken from a laboratory at the school. Mr. Guy's parents subsequently filed a wrongful death lawsuit against MIT claiming "gross negligence" and "failure to meet its duty of care." (Lang, 2002). MIT eventually agreed to a settlement with the parents of Mr. Guy, without admitting any liability in the matter. (Rivoire, 2005).

\subsection{The Case of Jason Starn}

In 2010, Jason Stam, a school teacher and law student in California, nearly died after purchasing and inhaling small nitrous oxide filled canisters used for whipping cream known as a Whip-it! It is also worth noting that in order to obtain an illegal high from Whip-it! the buyer must also purchase a separate tool known as a Cracker, a puncture device. However, this device is not made or designed by Whip-it! or sanctioned by the manufacturer to be used with the canisters. Starn had been a frequent customer of Smoke island, a tobacco and smoke shop in Modesto. Starn stated that he had been regularly inhaling the gas when one day after inhaling a canister, he lost feeling below his rib cage. The numbness eventually wore off, but Starn suffered a degeneration of his spinal cord which he claimed was directly related to his use of the nitrous oxide canisters.

In the law suit filed in 2012 (Starn v. Smoke Island, 2012), Starn claimed that he sustained his after inhaling nitrous oxide which had been sold to him by Smoke Island, and that the store had a duty to warn of the dangers of using nitrous oxide in such a manner as would be foreseeable under the circumstances. In the alternative, Starn asserts by implication that Smoke Island should not have sold it to him in the first place because of the hamful and dangerous nature of the product. Starn was incapacitated and confined to the use of a wheel chair. Smoke Island, the defendant, is a retailer of tobacco and smoking related products, and not a retailer of kitchen or food-related supplies.

According to Starn's attorney, Deborah Barron, Starn filed a lawsuit against Smoke Island as a warning to others. Ms. Barron states that her client found out the "hard way" that the Whip-it!s are not the hamless product many believe them to be. Barron stated that the lawsuit was intended to let the public know that Whip-it!s in fact are a harmful product and can kill or seriously injure the user. Ms. Barron conceded that her client was inhaling a Whip-it!, but that had no idea that his life and health were in danger. (Barron, 2012). The lawsuit may be the first of its kind in the state of Californiaaccording to Barron, the case is unprecedented. The plaintiff filed suit under provisions of the California Business and Professions Code which apply to mislabeled products. (Cited in Furillo, 2013).

Starn has not directly claimed either a manufacturing or design defect. Rather, Starn has focused on a potential marketing defect and maintained that Smoke Island failed to provide an adequate warning relating to the dangers associated with the inhalation of nitrous oxide canisters. However, as has been noted, the manufacturer of the Whip-it! did print a "Do Not Inhale" warning on its packaging and has a disclaimer regarding misuse posted on its website. Two questions arise: In this context, should Whip-it! and Smoke Island have reasonably foreseen that the product which they manufactured or sold would be used illegally and would cause ham to Mr. Starn? Secondly, is the waming legally adequate, given that the product is intended by the manufacturer and retailer to be used for the lawful purpose of whipping cream or is it legally inadequate, considering that the manufacturer may have knowledge that the product is being misused?

\subsection{The Defense}

In response to Starn's allegations, the defense cited the case of Jenkins v. W.L. Roberts, Inc. (2003) as a precedent.

The facts of Jenkins were outlined in the appellate opinion. W. L. Roberts, Inc. is a retail hardware and auto racing supply store in Crawfordville, Florida which sold nitrous oxide to a customer named Tyler Augat sometime before November 7, 1998. On November 7,1998, Augat was a passenger in a car driven by James Kelly Goddard. Augat and another passenger were inhaling the nitrous oxide (commonly referred to as "huffing") during the ride. Goddard's vehicle veered off the road, striking a steel I-beam sign pole. Goddard sustained fatal injuries. The autopsy report also showed nitrous oxide in Goddard's system at the time of death.

On September 9, 1999, Rita Jenkins, as personal representative of the estate of James Kelly Goddard, filed a complaint against W. L. Roberts, Inc. for the wrongful death of her 22 -year-old son. To establish a cause of action for negligence in a wrongful death action, a plaintiff must allege and prove (1) the existence of a legal duty owed to the decedent, (2) breach of that duty, (3) legal or proximate cause of death was that breach, and (4) consequential damages. (Fritsch v. Rocky Bayou Country Club, Inc., 2001). The element of negligence relating to a duty of due or reasonable care is a threshold legal question to be decided by the court as a matter of law. If no legal duty exists, then no action for negligence may lie. (McCain v. Florida Power Corp., 1992; Menendez v. Palms West Condo. Ass'n., 1999).

The complaint alleged that James Kelly Goddard lost consciousness and crashed his car as a direct result of inhaling nitrous oxide given to him by his passenger, Mr. Augat, who had purchased the nitrous oxide from W. L. Roberts, Inc. The complaint alleged that W. L. Roberts, Inc. had a duty to take reasonable care to ensure that the nitrous oxide sold at its store would not be used as an inhalant, but would be only used for the lawful purpose of enhancing the engine performance of race cars. The complaint further alleged that the defendant breached its duty by failing to take 
reasonable precautions to ensure that the nitrous oxide sold in its store would be used for its lawful purpose, and that defendant's failure to take such reasonable steps was the proximate cause of Goddard's death.

The complaint cited sections 499.039 and 877.111(2) of Florida Statutes (1997). Section 499.039 made it unlawful for a person to "sell, deliver, or give to a person under the age of 18 years any compound, liquid, or chemical containing ... . nitrous oxide ... for the purpose of inducing by breathing, inhaling, or ingesting a condition of intoxication or which is intended to distort or dis turb the auditory, visual, or other physical or mental processes."

In response, the defendant asserted that there was no direct evidence on the key issue of causation to establish that Goddard had inhaled the nitrous oxide purchased from the defendant's store; no evidence that Goddard had lost consciousness while driving, causing him to hit a steel pole; and no evidence that even if Goddard lost consciousness, it was caused by the inhalation of nitrous oxide. The defendant also asserted that the injuries and subsequent death of Goddard as a result of Augat supplying Goddard with the product as described in the complaint were not foreseeable as a matter of law, given the independent and intervening nature of the events surrounding the accident in which Goddard had lost his life.

The pleadings and the deposition transcript of Tyler Augat contained Augat's testimony that he purchased nitrous oxide from the defendant's store the day before the accident. Augat further testified that he was 25 years old at the time of the purchase and that he told the store he was purchasing the nitrous oxide for the purpose of enhancing performance of his automobile for racing. The appellate court made additional findings of fact:

"There is no evidence in the record, and the appellant did not allege, that the person who bought the nitrous oxide, Tyler Augat, was under the age of 18 at the time the store sold it to him; there is no competent evidence in the record that the store sold nitrous oxide to him or anyone under the age of 18 with the knowledge that they intended to inhale it. Although the appellant alleged in paragraphs 11 and 12 of the complaint that the store "knew or should have known" that the nitrous oxide sold to Tyler Augat was intended to be used as an inhalant or that Mr. Augat might distribute the nitrous oxide to others for inhaling, there is no competent evidence in the record that anyone associated with the auto parts store knew that Tyler Augat purchased the nitrous oxide with the intention of inhaling it or with the intention of giving it to a third party to inhale. The affidavits of Kevin Roberts, Walter Roberts, and Beverly Roberts contain sworn statements that there was no such knowledge. Absent special circumstances, there is no legal duty requiring a store to ensure that a product lawfully sold will ultimately be used by a customer or unknown third party for a lawful purpose." (Jenkins v. W.L. Roberts, Inc., 2003).

The trial court granted summary judgment in favor of the defendant, relying on Guice $v$. Enfinger (1980) and Bryant $v$. Jax Liquors (1977). It found that the defendant's use of nitrous oxide by a passenger in the Goddard vehicle was not foreseeable and was not the proximate cause of Mr. Goddard's death. The court also found that the defendant owed no legal duty to Mr. Goddard under these circumstances.

\section{BACK TO STARN-AND SOME TENTATIVE CONCLUSIONS}

The main question presented in Starn is whether or not Smoke Island and Whip-it! breached their duty to the plaintiff by failing to eliminate a reasonably foreseeable risk of harm associated with the nitrous oxide canisters through an adequate waming about the dangers of inhalation? The case also raises question relating to Starn's own contributory negligence (whether the plaintiff created a fores eeable, unreasonable risk to his own safety) (Fischer \& Powers, p. 524, 1988); possible assumption of risk (involving a plaintiff who voluntarily encounters a risk that he subjectively knows and appreciates) (Fischer \& Powers, p. 532, 1988); and misuse of the product (when the product is used "for a purpose not reasonably foreseeable to the manufacturer" or when the product is used "in a manner not reasonably foreseeable for a reasonably foreseeable purpose.") (Perfection Paint \& Color Co. v. Konduris, 1970; Cornette v. Searjeant Metal Products, 1970). It should be noted that: "Nomally a seller or manufacturer is entitled to anticipate that the product he deals in will be used only for the purposes for which it is manufactured and sold; thus he is expected to reasonably foresee only injuries arising in the course of such use." (Spruill v. Boyle-Midway, Inc., p. 83, 1962).

In seeking answers to these questions, it must be remembered that the canisters are lawfully used in cafes and restaurants for their intended use, which is whipping cream. As previously mentioned, the dangers of using this product have been well documented and that infomation is readily available on the intemet. The Restatement (Second) of Torts, Section 402A, comment j (1965) states:

"A seller is not required to wam with respect to products or ingredients in them, which are only dangerous, or potentially so, ... when the danger, or potentiality of danger, is generally known and recognized."

Starn has admitted to using the canisters for illegal purposes for an extended period of time. The argument can be made that Starn may have read the "Do Not Inhale" warning on the box of canisters, understood it, ignored it and proceeded to act contrary to the waming. In the altemative, there is a strong indication that Starn might not have been deterred from engaging in the risky and illegal behavior even had he read the warnings provided by the manufacturer of the product, or Smoke Island, the seller. However, in either case, comment $j$ to Section 402A of the Restatement would be powerful evidence casting doubt on the potential liability of the seller.

Starn's actions of ignoring the waming label while using the product for illegal purposes resulted in his injury and should also ultimately result in a dismissal of the negligence claim brought against Smoke Island. 


\section{APPENDIX I}

\section{What is Inhalant Abuse?}

"Inhalant abuse" refers to the deliberate inhalation or sniffing or fumes, vapors or gases from common household products for the purpose of "getting high." Unfortunately, canned whipped creams and toppings are just one example of products that are commonly misused. When used as intended, canned whipped creams and toppings are a nice addition to a dessert, fruit, or beverage. However, when abused the y may prove harmful.

Different inhalants yield different effects, yet generally speaking, because inhaled chemicals are absorbed through the lungs into the bloodstream and distributed to the brain and other organs, the effects of inhaling can be severe. Within minutes, the user experiences feelings of intoxication and may become dizzy, have headaches, abdominal pain, limb spasms, lack of coordination, loss of control, hallucinations, and impaired judgment. Worse, he or she may even die from a condition known as Sudden Sniffing Death Syndrome, which can even occur with first time users.

Long-term inhalant users generally suffer from muscle weakness, inattentiveness, lack of coordination, irritability, depression, liver or kidney damage and central nervous system (including brain) damage. The dangers are real, the side effects are severe and the high is not worth risking your life.

\section{http:/www.inhalant.org/faqs/whippets/\#sthash.9PDulpXG.dpuf}

\section{From the Whip-it! Website:}

\section{APPENDIX II}

Cream whippers and charger systems are invented by Whip-It's original manufacturing partner in Switzerland in 1950's. Whip-It! Brand whippers and chargers reflect over 60 years of manufacturing expertise and the brand name is synonymous with the "cream charger" product category itself.

Today, the Whip-It! products are made to the highest quality standards in the world, manufactured at ISO 9001 , ISO 9002,TUV certified factories. The Whip-It! Brand professional cream whippers are the superior in quality and design, and has been the leader in terms of quality and efficiency in food service. Many of the nations' top restaurants and coffee chains rely on the Whip-It! cream dispensers and cream chargers. The cream whippers have NSF certifications and are HACCP compliant.

The nitrous oxide used in our Whip-It ${ }^{\mathrm{TM}}$ brand charges is of the highest medical grade quality.

Fresh, natural and non-preservative gourmet whipped cream compared to aerosol cans with chemicals.

Great savings compared to pre-packed aerosol canned whipped cream.

Cream whippers, chargers and soda siphon systems are a green solution that minimizes the huge eco-footprint caused by the manufacture, transport and waste of aerosol cans and bottled water.

With cream whippers, you have the opportunity to flavor your whipped cream with endless options such as fruit flavors, chocolate, powdered sugar altematives, among many! Flavoring options for the soda water is no less; regular, diet, natural, fruity flavors, Italian sodas and many more.

Our process: guaranteed quality: certification and processes

- The Whip-it! brand chargers are manufactured according to the DIN 32615 standard which is the only specific standard for 8 gram N2O chargers and CO2 chargers. The DIN 32615 not only details all geometric, material, filling and content specifications, but also regulates the fact that the production facilities have to be checked in every detail. A company with this certification process guarantees the highest quality chargers.

- All 8 gram N2O and CO2 chargers are cleaned twice during the manufacturing process. The final cleaning prior to filling is a wash with an environmentally friendly solvent to remove any oils and residue. All chargers are then dried with steam to avoid over heating and to sterilize.

- All Whip-it! brand standard 8 gram chargers are filled and individually weighed according to the above standard. The factory which manufactures the Whip-it! brand chargers is ISO 9001 and ISO 14001 certified. By combining the TUV and ISO certification, you are assured of the finest-quality products available.

- Due to the high standard of the ISO 9001 standards, each batch is inspected and a random test is performed by cutting chargers open for inner inspections.

- The cartridges are filled to + or - .5 grams. The purity of the N2O chargers meets the requirements for Pharmacopoeia Eur. III and VII Pharmacopoeia HG. This is the specification for medical grade gas. 
- Upon completion of the filling process, all chargers are put into a high temperature $\left(65-70^{\circ} \mathrm{C}\right)$ tumbling machine for leak testing. After this process all cartridges are stored for a minimum of 24 hours after which each cartridge is weighed to ensure the correct fill. Cartridges are then packed for shipping.

\section{REFERENCES}

1. Allen, J. 2015. "Whip-lts: Big Highs, Big Dangers for Demi Moore." ABCNews.com, at http://wwwabcnews.go.com/Health/whip-highs-big-dangers-demi-moore/story?id=.

2. Ausness, R. 2012. "“Fasten Your Seat Belt, Orville!" Exploring the Relationship Between State-of-the-Art, Technological and Commercial Feasibility, and the Restatement's Reasonable Alternative Design Requirement." Indiana Law Review, 45: 669-717.

3. Barron, D. 2012. "Whip-lts - Cheap Thrill or Dangerous Product?" Press Release, March 29, at http://www.pr.com/press-release/398993.

4. Bernstein, A. 2013. "Voluntary Recalls." University of Chicago Legal Forum, 359-407.

5. Braucher, J. 1985. "An Informal Resolution Model of Consumer Product Warranty Law." Wisconsin Law Review, 1405-1480.

6. Browne, M.N. and Biksacky, L. 2013. "The Significance of the Distinction Between Children and Adults for Consumer Protection." Loyola Consumer Law Review, 25:185-228.

7. Committee on Standard July Instructions, Civil. 1986. California Book of Approved Jury Instructions, Nos. 9.00.3, 9.00.5, 9.00.7 (7th ed.).

8. Fisher, D. and Powers, Jr., W. 1988. Products Liability: Cases and Materials. West.

9. Florida Statutes. 1997. Sections 499.039 and $877.111(2)$.

10. Furillo, A. 2013. "California man is suing head shops over n2o addition leading to spinal cord damage." The Sacramento Bee, Jan. 3, at https://drugs-forum.com/forum/showthread.php\%3Ft\%3D209694.

11. Galligan, T. et al. 2007. Tort Law: Cases, Perspectives, and Problems. Lexis Nexis.

12. Hunter, R., Amoroso, H. and Shannon, J. 2012a. "Managerial Guide to Products Liability: Part I- A Primer on the Law in the United States." International Joumal of Learning and Development, 2(3):34-56.

13. Hunter, R. Amoroso, H. and Shannon, J. 2012b. "A Managerial Guide to Products Liability: A Primer on the Law in the United States: Part II- A Focus on the Theories of Recovery." International Joumal of Leaming and Development, 3: 99-122.

14. Hunter, R. and Montuori, M. 2013. "The Hand that Truly Rocks the Cradle: A Reprise of Infant Crib Safety, Lawsuits and Regulation from 2007-2012." Loyola Consumer Law Review, 25: 229-247.

15. Lang, K. 2002. "Wrongful Death Suit against MIT Filed by Parents of Richard Guy." The Tech Online Edition, 122(54), November 8, at http://tech.mit.edu/V122/N54/54guy.54n.html

16. Montal, I. 1989. "The Consumer Expectations Test in New Jersey: What Can Consumers Expect Now?" Brooklyn Law Review, 54: 1381-1412.

17. Owen, D. 2008. "A Tribute to Professor David Fischer: Design Defects." Missouri Law Review, 73:291-365.

18. Restatement (Second) of Torts. 1965. Section 402A comment $f$, comment $j$.

19. Restatement (Third) of Torts. 1997. "Products Liability," Section 2.

20. Rivoire, K. 2005. "Guy Family and MIT Settle Lawsuit, Plan New Memorial Fund." The Tech (online edition), 125(29), July 6, at http://tech.mit/edu/V125/N29/guy.html.

21. Substance Abuse and Mental Health Services Administration (SAMHSA). 2008, 2013. "National Survey on Drug Use and Health," "Nat http://www.samhsa.gov/data/sites/default/files/NSDUHresultsPDFWHTML2013/Web/NSDUHresults2013.

22. Texas Civil Practice and Remedies Code, as amended. 1987.

23. Unifom Commercial Code. 1952/1999.

24. Wade, J. 1973. "On the Nature of Strict Tort Liability for Products." Mississippi Law Journal, 44: 825-851.

25. Whip-it! Brand (Website). 2015. http://www.whipitbrand.ca. (last visited June 5, 2015).

\section{CASES CITED}

Boatland of Houston, Inc. v. Bailey, 609 S.W.2d 743 (Supreme Court of Texas, 1980). 
Borel v. Fireboard Paper Products Corp., 493 F.2d 1076 ( $5^{\text {th }}$ Circuit Court of Appeals, 1973).

Bryant v. Jax Liquors, 352 So. 2d 542 (Florida $1^{\text {st }}$ District Court of Appeals, 1977).

Burch v. Sears Roebuck, 467 A.2d 615 (Pennsylvania Superior Court, 1983).

Center Chemical Co. v. Parzini, 218 S.E.2d 580 (Supreme Court of Georgia, 1975).

Cornette v. Searjeant Metal Products, 258 N.E.2d 652 (Indiana Court of Appeals, 1970).

Cover v. Cohen, 461 N.E.2d 864 (Court of Appeals of New York, 1984).

Daubert v. Merrell Dow Pharmaceuticals, 43 F.2d. 1311 ( $9^{\text {th }}$ Circuit Court of Appeals, 1995).

Davis v. Wyeth Laboratories, Inc., 399 F.2d 121 ( $9^{\text {th }}$ Circuit Court of Appeals, 1968).

Escola v. Coca-Cola Bottling Co., 150 P.2d 436 (Supreme Court of California, 1944).

Feldman. v. Lederle Laboratories, 479 A.2d 374 (Supreme Court of New Jersey, 1984).

Ford Motor Co. v. Bland, 517 S.W.2d 641 (Court of Civil Appeals of Texas, Tenth District, 1974).

Fritsch v. Rocky Bayou Country Club, Inc., 799 So. 2d 433 (Florida $1^{\text {st }}$ District Court of Appeals, 2001).

Garnes v. Gulf \& Western Mfg. Co., 789 F.2d 637 ( $8^{\text {th }}$ Circuit Court of Appeals, 1986).

Gray v. Manitowoc Co., Inc., 771 F.2d 866 ( $5^{\text {th }}$ Circuit Court of Appeals, 1985).

Greenman v. Yuba Power Products, Inc., 377 P.2d 897 (Supreme Court of California, 1963).

Guice v. Enfinger, 389 So. 2d 270 (Florida $1^{\text {st }}$ District Court of Appeals, 1980).

Henningsen v. Bloomfield Motors, 161 A.2d 69 (Supreme Court of New Jersey, 1960).

Jenkins v. W.L. Roberts, Inc, 851 So.2d 781 (Florida $1^{\text {st }}$ District Court of Appeals, 2003).

Kinser v. GEHL Company, 184 F.3d 1259 (10 ${ }^{\text {th }}$ Circuit Court of Appeals, 1999).

Lee v. Volkswagen of America, Inc., 688 P.2d 1283 (Supreme Court of Oklahoma, 1984).

Levin v. Walter Kidde \& Co., 248 A.2d 151 (Court of Appeals Maryland, 1968).

Lukaszewicz v. Ortho Pharmaceutical Corp., 510 F. Supp. 961 (Eastem District Wiscons in, 1981).

MacPherson v. Buick Motors, 111 N.E. 1050 (Court of Appeals of New York, 1916).

Martinez v. Dixie Carriers, Inc., 529 F.2d 457 ( $5^{\text {th }}$ Circuit Court of Appeals, 1976).

McCain v. Florida Power Corp., 593 So. 2d 500 (Supreme Court of Florida, 1992).

Menendez v. Palms West Condo. Ass'n., 736 So. $2 d 58$ (Florida $1^{\text {st }}$ District Court of Appeals, 1999).

Mickle v. Blackmon, 252 S.C. 202, later app. 255 S.C. 136 (Supreme Court of South Carolina, 1970).

Natural Gas Odorizing v. Downs, 685 N.E.2d 155 (Indiana Court of Appeals, 1997).

Perfection Paint \& Color Co. v. Konduris, 258 N.E.2d 681 (Indiana Court of Appeals, 1970).

Reyes v. Wyeth Laboratories, 498 F.2d 1264 ( $5^{\text {th }}$ Circuit Court of Appeals, 1974).

Rix v. General Motors Corp., 723 P.2d 195 (Supreme Court of Montana, 1986).

Spruill v. Boyle-Midway, Inc., 308 F.2d 79 (4 ${ }^{\text {th }}$ Circuit Court of Appeals, 1962).

Starn v. Smoke Island. (2012). Filed under 00127576-CU-P0 (California Civil).

Tincher v. Omega Flex, Inc., 64 A.3d 626 (Supreme Court of Pennsylvania).

Thomas v. Winchester, 6 N.Y 397 (Court of Appeals of New York, 1852).

Toole v. Baxter Healthcare Corp., 235 F.3d 1307 (11 ${ }^{\text {th }}$ Circuit Court of Appeals, 2000).

Welch v. Outboard Marine Corporation, 481 F.2d 252 ( $5^{\text {th }}$ Circuit Court of Appeals, 1974).

Richard J. Hunter is Professor of Legal Studies in the Stillman School of Business at Seton Hall Univers ity. He has been an adjunct professor at the Seton Hall and Rutgers (Newark and Camden) Schools of Law for over two decades.

Professor Hunter holds a JD from the University of Notre Dame and a Masters from the Johns -Hopkins School of Advanced International Studies. He has published nearly 140 research papers and articles and made nearly 200 research presentations during his career. Sandra Solano completed her MBA from Seton Hall University in 2015 and was a student in Professor Hunter's Products Liability class where her paper was selected as the outstanding graduate research paper, serving as the seminal research for this article. 